\title{
Tax Fairness Perceptions and Compliance Behavior: Evidence from the Metropolitan Cities of the Amhara Regional State of Ethiopia
}

\author{
Samuel Alemnew Belay ${ }^{1}$, P. Viswanadham ${ }^{2}$ \\ ${ }^{1}$ Andhra University, Department of Commerce \& Management Studies, Visakhapatnam, India \\ ${ }^{2}$ Professor, Andhra University, Department of Commerce \& Management Studies, Visakhapatnam, India
}

\begin{abstract}
The main objective of this study was to examine the tax fairness perceptions and compliance behavior of business income taxpayers in the metropolitan cities of the Amhara Regional State of Ethiopia. A cross-sectional survey research design and a qualitative research approach were adopted in this study. Purposive sampling technique was employed to select the study participants. The sample size for the purpose of this study was 24. The data was collected using semi-structured interviews. Data gathered from interviews were analyzed using thematic analysis, a method that identifies analyses and reports patterns within data. From the analysis, the results suggest that participants had mixed perceptions on the fairness of the income tax system. Specifically they had concerns on six aspects of fairness perceptions, namely: general fairness, horizontal fairness vertical fairness, retributive fairness, personal fairness and administrative fairness. These concerns should at least provide a signal to the Revenue Authority on the aspects of income tax system that need improvements. Based on the findings above in this study it is possible to conclude that business income taxpayers have multidimensional perceptions on the fairness of the income tax system. Moreover, the impact of fairness perception on the decisions of taxpayers whether to comply or not to comply with the income tax system was found to be paramount. Therefore the recommendations out of this study were: (1) The revenue Authority should consider the socio-psychological aspects of the taxpayer s' in addition to the economic deterrence approaches while developing the tax policy in order to make the policy implementation easy and (2) To enhance the level of tax compliance the tax authority should take the perceived tax fairness issues with all its dimensions into account.
\end{abstract}

Keywords: Fairness perception, compliance behavior, income tax system

\section{Introduction}

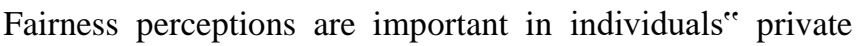
and public lives. Equality, justice and social change all have their roots in perceptions of fairness. If individuals perceive a system or situation to be fair, they will generally support the system and demonstrate this support through their actions. According to Lind \& Tyler (1988) ${ }^{[1]}$ and Rasinski \& Tyler (1988) ${ }^{[2]}$ the impact of perceived fairness has been established by political psychologists who claim that citizens make political evaluations based on fairness perceptions.

Undeniably tax fairness is one important element of an efficient tax system. In taxation, fairness perceptions have been discussed widely internationally and have been seen as a prerequisite for taxpayers ${ }^{\text {e }}$ compliance behavior. In fact, there is excess overseas evidence documenting the role of tax fairness in the tax system. Etzioni (1986) ${ }^{[3]}$, for example, conclude that fairness perceptions of tax are more important than the tax rate itself in influencing compliance behavior. A study by Bordignon(1993) ${ }^{[4]}$ further documented that fairness has an important influence on taxpayers ${ }^{\text {ee }}$ compliance behavior. Tax compliance has long been a prevalent issue in many countries. In 2006, the Internal Revenue Service (IRS) estimated that the United States has about $\$ 300$ billion tax gap, which is the amount of income taxes not collected due to noncompliance Alm \& Mckee $(2006){ }^{[5]}$. Tax compliance situation outside the United States are even worse Slemrod (1992) ${ }^{[6]}$.

Most tax compliance studies are about the tax systems in the United States and other developed countries. There are relatively few studies analyzing tax compliance in developing countries, mainly because of data availability problems Alm (1999) ${ }^{[7]}$. Studies of tax compliance are also very limited in Ethiopia with only a few studies on the tax system, tax fairness and tax compliance issues (Taddese, 2014 ${ }^{[8]}$; Wubshet, 2011 ${ }^{[9]}$; Asmamaw, 2014) ${ }^{[10]}$. In his study of the income tax system of Ethiopia Tadese $(2014)^{[8]}$ emphasized on the legal aspects of the existing tax system and its practice such as tax equity. According to Taddese (2014) ${ }^{[8]}$, "in order to discover that the Ethiopian income tax system discriminates among taxpayers, it is not at all necessary to engage in inter-scheduler comparisons of how Schedule "A" taxpayers fare vi's-à-is that of Schedule "B" or Schedule "C" or Schedule " $D$ ". Taxpayers subject to the same schedule are often the subject of discrimination". A study conducted by Wubshet (2011) ${ }^{[9]}$ on Addis Ababa personal business profit taxpayers about their fairness perception of the income tax system concluded that they perceived the system as unfair. A Comparative Study of Compliant and Non- Compliant Individual Taxpayers in Ethiopia evidence from Amhara regional, state conducted by Asmamaw (2014) ${ }^{[10]}$ revealed that tax morals, tax fairness and to a lesser degree in tax enforcement and tax awareness both directly and indirectly impacted upon taxpayer compliance.

A common feature of the tax structure of low-income countries like Ethiopia is the fact that indirect taxes constitute the lion "es share. According to Tsegabirhan (2010) ${ }^{[11]}$ for a study period of about 30 years (1979-80 to 200708), the relative importance of direct taxes in Ethiopia has remained low: averaging 37 per cent of total tax revenues. In fact, despite expectations of improvement, the share of direct taxes has declined from about 40 per cent in the period $1979-80$ to $1991-92$ to about 34 per cent during 1992-93 to 2007-08. Surprisingly, it is continuing to decline, despite the 


\section{International Journal of Science and Research (IJSR) \\ ISSN (Online): 2319-7064 \\ Index Copernicus Value (2013): 6.14 | Impact Factor (2015): 6.391}

expectation that it would increase following changes in the tax policies since around the mid 1990. Obviously the reason behind the poor performance of the direct taxes, especially the business income tax is due to the existence of high level noncompliance and in turn the high noncompliance is assumed to be caused by the application of excessive enforcement mechanisms and ignoring the behavioral aspects of tax compliance decision making issues of income tax payers such as tax fairness.

Beginning with the establishment of a separate tax administration body in 1995, successive reforms were undertaken in the organization of tax administration, culminating in the merger of the separate tax authorities and establishment of the Ethiopian Revenues and Customs Authority (ERCA) in 2008. This reorganization did not simply merge the separate authorities at the time, but affected many other areas of Ethiopian tax administration. The upshot of those reforms was to strengthen the arm of ERCA in many areas of tax administration: assessment, collection, investigation and enforcement. ERCA's powers of investigation and prosecution were strengthened quite considerably when the established laws conferred original jurisdiction over the investigation and prosecution of tax and customs offenses. As a result of these reforms in tax administration, ERCA has emerged as one of the most powerful government bodies of both the Federal and regional Governments.

In the last decade alone, the Ethiopian Government introduced major tax administration reforms with a view to improving the performance of Ethiopian tax administration in generating revenues for the Government. Some of these reforms included the introduction of the Tax Identification Numbers (TIN), the obligatory use of the cash-register machines by many taxpayers and the installation of a number of information technologies to improve the performance of the Ethiopian Tax Administration. Despite all the tax reform measures taken, the behavioral aspects of tax compliance decision making issues of income tax payers the performance of the Ethiopian tax system has not improved quite considerably over the last decade. For instance, the tax-to-GDP ratio has been far lower than even the Sub-Saharan average. Ethiopian current tax-to-GDP ratio of $11 \%$ is far lower than the average for developed tax systems (25-35\%), developing countries (18-25\%) and even of the Sub-Saharan average (16\%).

There is a paradox in the Ethiopian tax system in general and in the income tax system in particular. One of the fastest growing economies in the world as per IMF $(2015)^{[12]}$ with a highly authoritative tax authority failed to finance its activities by its own means due to noncompliance even after a series of tax system reforms. Therefore the intent of this study was to contribute in solving the puzzle by exploring the fairness perception with its dimensions and compliance behavior issues which influence taxpayers ${ }^{\text {ee }}$ level of compliance.

With the exception of a few scholarly articles written on the Ethiopian income tax system in the 1980s and 1990s and a limited number of student theses written on a variety of subjects involving Ethiopian income tax system, the
Ethiopian income tax system has attracted a scant amount of scholarly attention. The absence of critical studies on the Ethiopian income tax system, especially on the behavioral aspects of tax compliance decision making issues of income tax payers makes this study one of the few sustained studies on the Ethiopian income tax system in general and on the Amhara Regional State of Ethiopia income tax system in particular.

\section{Objective of the Study}

The major objective of this study is to understand how business income taxpayers in the metropolitan cities of the Amhara Regional State of Ethiopia perceive the current income tax system and compliance behavior issues. Specifically, the study will pursue the following objectives:

1) To confirm whether business income taxpayers have multi-dimensional perceptions on the fairness of the income tax system.

2) To investigate the role of fairness perceptions on taxpayers ${ }^{\text {ee }}$ compliance behavior

\section{Theories and literatures Reviews}

\subsection{Equity Theory}

The first theory addressing fairness perceptions that is relevant for this research is Equity Theory. Equity Theory emerged in the 1960s through the work of Adams (1965) ${ }^{[13]}$ who was particularly interested to test the concept of justice in organisations Greenberg, $(1987)^{[14]}$. Since then, Equity Theory has been extended (Eckhoff, 1974 ${ }^{[15]}$; Leventhal et al., 1980 ${ }^{[16]}$; Thibaut \& Walker, 1975)[17] and applied in various fields of studies, such as payment and job-related rewards (Aryee et al., 2004 ${ }^{[18]}$; Campbell \& Pritchard, $1976^{[19]}$; Watson et al., 1996) ${ }^{[20]}$, taxation (Bobek, 1997 ${ }^{[21]}$; Carnes \& Cuccia, $1996^{[22]}$; Gilligan \& Richardson, 2005) ${ }^{[23]}$ and information systems (Douglas et al., 2007 ${ }^{[24]}$; Joshi, 1989) ${ }^{[25]}$.

Adams (1965) ${ }^{[13]}$ suggests that Equity Theory comprises two dimensions namely reciprocation and allocation. Reciprocal equity, or exchange fairness, is based on the premise that one would only respond fairly if the other party acts fairly to them. Within this exchange framework, equity or fairness is achieved when there is an equivalence of the outcome/input ratios for all parties involved in the exchange (Cook \& Hegtvedt, 1983) ${ }^{[26]}$. Inequity, on the other hand, is said to exist when these ratios are not equal. In other words, a person will perceive a system as fair if the benefit he/she receives equals their contribution, and vice versa.

In contrast to reciprocal fairness, which deals with mutual exchange, Eckhoff (1974) ${ }^{[15]}$ contends that allocation fairness merely involves a one-way distribution of resources across a group or circle of recipients. This fairness dimension is also known as indirect exchange (Blalock \& Wilken, 1979) ${ }^{[27]}$.

\subsection{Distributive Justice Theory}

In order to extend the idea of allocation as suggested in Adam s (1965) ${ }^{[13]}$ Equity Theory, DJT was introduced. DJT, 


\section{International Journal of Science and Research (IJSR) \\ ISSN (Online): 2319-7064 \\ Index Copernicus Value (2013): 6.14 | Impact Factor (2015): 6.391}

which represents one part of Social Comparison Theory (Lamm \& Schwinger, 1980) ${ }^{[28]}$, postulates that individuals not only judge equity in terms of assessing their benefits they receive from their tax dollars (exchange fairness), but also by comparing themselves with others. In other words, individuals compare their benefits-received-to-contributionsratio with that of others in their reference group, and if individuals find a disparity, they find their dealings inequitable (Walster et al., 1978) ${ }^{[29]}$. Based on this premise, DJT assumes that distribution outcomes should be equal among those with similar contributions.

However, in the process of allocating an incentive or reward, the principle of exchange fairness is not always maintained. There are circumstances in which the allocation of rewards violates exchange fairness as indicated in previous studies (Greenberg, 1987 ${ }^{[14]}$; Schwinger, $1980^{[30]}$ ). Having this in mind, Leventhal (1976) ${ }^{[31]}$ contends that distributive fairness can be achieved by applying allocation rules, namely the equity rule, equality rule or needs rule, depending on the situation. In achieving fairness, the equity rule suggests that there must be relative equality between an individual's contribution and benefits. Simply stated, the equity rule requires individuals to be compensated with the same ratio to their effort, as stated in exchange fairness. In contrast, the equality rule calls for equal distribution of rewards regardless of individual contribution. The equality rule suggests that everyone deserves to be treated equally irrespective of his or her contribution. With the needs rule, Leventhal (1976) ${ }^{[31]}$ proposes that the allocation decision should be made after taking into account the recipients ${ }^{\text {ee }}$ needs. Based on this rule, individuals with a low or a zero contribution may be allocated more benefits (to fulfill their needs), as compared to those with a higher contribution.

\subsection{Procedural Justice Theory}

PJT, an extension of Equity Theory, was originally inspired by the contention in the legal context that a community's acceptance of judicial decisions is highly influenced by the procedures employed to formulate them (Fuller, 1961) ${ }^{[32]}$. Applying that foundation, Thibaut and Walker (1975) ${ }^{[17]}$ embark on a study of dispute resolution procedures and report two interesting findings. First, the disputants with process control perceive verdicts fairer than those without process control. Second, disputants that are involved in the decision-making process are more likely to accept the decisions even in the case of adverse outcomes. These findings conclude that procedural fairness is important as it enhances the acceptance level of the outcomes received. Based on the pioneering effort of Thibaut and Walker (1975) [17], Leventhal (1980) ${ }^{\text {[3] }}$ extends the notion of procedural justice into organisational settings contexts. Leventhal (1980) ${ }^{[33]}$ identifies six principles against which fairness of procedures may be evaluated, namely: consistency, bias suppression, accuracy, correctability, representativeness and ethicality.

A consistency criterion requires the allocative procedures be applied consistently among different individuals at all times. No one should be given privileges over another. In addition the consistency criterion also demands the allocative procedures remain constant without frequent change.
Regular alterations made to the procedures may lead to a violation of the consistency rule. When the consistency rule is violated perceptions of procedural fairness will decline.

A bias suppression criterion posits that prejudice should be avoided in allocative procedures. Everyone should be treated fairly without any discrimination or misconception. Allocative procedures which promote preferential treatment, or personal self-interest, will violate a bias suppression rule, and consequently procedural fairness will be perceived as unfair.

The accuracy criterion states that allocative decisions must be based on accurate information. This is essential since failure to collect and process accurate information will result in incorrect decision-making and jeopardise an individual ${ }^{\text {ee }} \mathrm{s}$ confidence in the fairness of the procedures adopted. Thus the accuracy criteria should be sustained to increase a positive perception of procedural fairness. Correctability deals with the opportunity to revise incorrect decisions made. This criteria requires a legitimate channel to modify decisions must exist as a prerequisite for allocative procedures to be perceived as fair. Representativeness is defined as the opportunity given to persons in the decisionmaking process. The rule postulates that the allocation process must represent the concerns of all recipients to ensure greater acceptance of the procedures.

The final criterion is ethics, which contends that allocation procedures must be based on prevailing moral and ethical standards. In the absence of the ethics rule, individuals may perceive that procedural fairness is violated and thus their fairness perceptions will be reduced. Previous studies adopting the six principles of Leventhal (1980) ${ }^{\text {[33] }}$ suggest consistency (Barret \& Tyler, 1986 ${ }^{[34]}$; Fry \& Cheney, $1981^{[35]}$ ) and representativeness (Makkai \& Braithwaite, $1996^{[36]}$ ), as the most important criteria in evaluating procedural fairness.

\section{Research Methodology}

For the study purpose, a cross-sectional research design was adopted. The research employed the qualitative approach in assessing the views of the business income taxpayers in the metropolitan cities of the Amhara Regional State of Ethiopia. The participants comprise respondents who have voluntarily expressed their willingness to participate in the study when asked by the investigator. The selection criteria were being the member of the sampling frame, the level of expertise related to the topic under study, the diversity of the business type and others. The majority participantse educational backgrounds were Accountants, lawyers, managers, lecturers and others. The sample size was 24 and for their selection a purposive sampling technique was employed. This study adopts semi-structured interviews to collect qualitative data. It is anticipated that this approach will provide richer and more accurate data for this study. The use of interviews is appropriate in obtaining either multifaceted or sensitive information, as well as understanding concepts which require elaboration (Hair et al., $2007^{[37]}$ ). Since fairness perceptions and compliance behavior are considered to be sensitive issues this approach appears to be suitable. 


\section{International Journal of Science and Research (IJSR) \\ ISSN (Online): 2319-7064 \\ Index Copernicus Value (2013): 6.14 | Impact Factor (2015): 6.391}

Ten questions were developed as a guide for the semistructured interview sessions. These questions were formulated with reference to the topics under study, that is: fairness perceptions, tax knowledge, tax complexity, and compliance behavior. A copy of the interview questions is included in Appendix 1.

Prior to the interview sessions, the confidentiality and anonymity of the respondents was reiterated to encourage their openness during the interviews. In this study, the personal interviews were conducted to enable the researcher to interview the participants in friendly, relaxed and interactive settings. So that the true feelings and perceptions can be observed even from various body languages and other expressions which could not be obtained in highly formal settings. In addition, it was expected that the participants would be more transparent in the face to face interview sessions. The interview was conducted from August 2015 to September 2015 and it took approximately thirty to forty five minutes per session to conduct - following the recommendations of previous researchers like (Synodinos, 2003) ${ }^{[38]}$ The conversations were recorded with the participants ${ }^{\text {ee }}$ permission to enable the researcher to transcribe them and analyze the data in the later stages of this study. Data gathered from interviews were analyzed using thematic analysis, a method that identifies analyses and reports patterns within data.

\section{Analysis and Results of Interview Data}

\subsection{Introduction}

The interview participants were allowed to communicate either in the Amharic language (Regional as well as Ethiopian national language) or in the English language or a combination of the two. However, for the purpose of analyzing and reporting the results, comments offered in the Amharic language were carefully translated by the researcher with the help of English language Lecturer. To distinguish between the translated versions from the original version (where the English language is used) in the text, the term non-translated ${ }^{\text {ee }}$ is used for the comments that are originally drawn from participants ${ }^{\text {ee }}$ own words (rather than being translated), at the end of the comments cited. The participants $^{\text {ee }}$ characteristics according to gender, employment sector and city, are set out in Table 8.1. In terms of gender, more than two-thirds were male participants and only six were females. The participants were representative of the three cities, with the majority from the city of Bahirdar ( 9 taxpayers). This is followed by the city of Gonder (8 taxpayers) and the city of Dessie (7 taxpayers) respectively.

The demographic description of the participants is presented in Table 1.1. The participants comprise 15 males and 9 females, from three metropolitan cities. In terms of participants level of education, eleven were BA/BSC degree holders while six participants were Masters and above. The remaining participants seven participants were diploma holders and below.
Table 1.1: Demographic Description of the Participants

\begin{tabular}{|l|c|}
\hline \multicolumn{1}{|c|}{ Gender } & Number \\
\hline Male & 15 \\
\hline Female & 9 \\
\hline Cities & \\
\hline Bahirdar & 9 \\
\hline Gonder & 8 \\
\hline Dessie & 7 \\
\hline Level of Education & \\
\hline Secondary/Technical school & 4 \\
\hline Diploma & 3 \\
\hline BA/BSC Degree & 11 \\
\hline Masters and above & 6 \\
\hline
\end{tabular}

\subsection{Data Analysis and Results}

\subsubsection{Fairness Perceptions of the Income Tax System}

When performing the step-by-step thematic analysis on the data as suggested by Braun and Clarke (2006) ${ }^{[39]}$, it was noticed that participants had mixed perceptions on the fairness of the income tax system. While some (33 percent) considered the income tax system to be reasonably fair, the majority (67 percent) were unhappy. Participants who viewed the income tax system to be fair considered the income tax system as a mechanism to redistribute wealth from the rich to the poor. In addition, some argued that paying tax is fair and not burdensome in the sense that it is part of a social responsibility that should not be avoided by any person living in a country. Others were satisfied with the income tax system on the basis that it is relatively stable and fairly treat the income taxpaying society as a whole. For example, one respondent observed:

"I think it"s reasonably fair to the society because of the fairly recent modifications to it by the current government or the intentions of the current government. In other words, I think nobody is heavily overtaxed and there doesn 'i seem to be an easy way which people can avoid tax, which is a good thing....In that sense, I think the tax system is reasonable and yes, right, I think it is a fair tax." (Participant 15, Female, from Gonder)

Despite the fact that some of the participants were generally happy with the overall income tax system, from the interviews, it appeared that participants were not completely satisfied with aspects of the current income tax system. For example:

"I think yeah [the income tax system is fair], but it could always possible to fine tune it....The only issue I do have is, I think there is some unfairness around penalties..." (Participant 4, Female, from Dessie)

I think it"s fairly fair. I don't really have any argument with it. I don't mind giving the money, but I don't expect that the money is used properly." (Participant 7, male, from Dessie)

"I am unhappy with the system. I have never been happy with what they do with the money."

(Participant 12, Female, from Gonder)

When probed further on their concerns about the fairness of the income tax system, their perceptions can be grouped into 


\section{International Journal of Science and Research (IJSR) \\ ISSN (Online): 2319-7064 \\ Index Copernicus Value (2013): 6.14 | Impact Factor (2015): 6.391}

several aspects of fairness. Participants with negative perceptions on the fairness of the income tax system had also given various explanations to justify their views. For instance, there was a claim that fairness of the income tax system should be determined based on: (1) how tax is collected; and (2) how tax revenue is spent. If fairness was defined in this manner, some taxpayers would have improved perceptions of the fairness of the income tax system. Otherwise, the income tax system would be perceived as not fair according to some participants. For example:

"In terms of tax fairness and perceptions or perceptions of fairness, whatever, I guess that I see there are two sides of the tax issue: one is the tax government received over tax paid by [taxpayers] and the other is the government expenditure, how they spent the tax." (Participant 13, male, Gonder)

While the majority of participants agreed with the views that fairness perceptions should encompass efficient tax collection and proper government spending, their opinions on the fairness of the income tax system went far beyond those two aspects of the income tax system. This is supported by the analysis performed on taxpayers ${ }^{\text {ee }}$ views on fairness perceptions, which subsequently generated six main themes of fairness perceptions:

1) General fairness;

2) Vertical fairness;

3) Retributive fairness;

4) Personal fairness

5) Administrative Fairness

6) Horizontal Fairness

\subsubsection{General Fairness}

With regard to general fairness, participants had mainly discussed three interrelated issues, namely: (i) an inefficient use of tax revenues by the government; (ii) a lack of disclosure of government expenditure and (iii) corruption. In relation to government spending, participants claimed that taxpayers $^{\text {ee }}$ money was wasted as a result of the government's incompetency. Despite having promising national plans and a yearly budget in place, the outcomes from such national plans were not readily visible and satisfactory to the public. This issue of inefficient spending was of more concern when the basic infrastructure, such as schools and hospitals were not well taken care of. Moreover, the results from the interviews indicated very few were satisfied with the government spending of the tax revenues, with the majority signaling their great disappointment concerning this issue. These participants firmly believed that tax revenues were not being properly spent in desired areas, such as health and education, and instead were wasted on government bureaucracy and defense. This has led to the violation of trust in the government, as indicated by the following comments:

"I guess the key thing is that the question of how the tax has been used. That is obviously going to influence people"s thought[s] about the whole tax system. [At] the moment that I would have thought that perhaps the tax birrs [tax revenue] have not been necessarily used effectively [by the government], (so) that would have influenced my [negative] thought[s], I guess." (Participant 8, male, from Gonder)

"...I don't expect that the money is used properly...What people get really annoyed about is when they see that money is being used by people who don't need it, or abuse it, in other words, money which is not properly applied by the government.” (Participant 4, Female, from Dessie)

״. . . sometimes, we are so much frustrated because oftentimes we look at the government expenditures, it is not what we expect, too huge amount is being wasted. ${ }^{\text {cee }}$ (Participant 5 male, from Dessie)

"I honestly feel that a lot of that money taken by [the] tax office is actually wasted and so I believe that can happen with any country in the world, but the one thing that does annoy me is that you earn your money, put it away and [the government] just blow them on the useless scheme that does not make any sense to me whereas that money should be used for example in the health department. (Participant 24, male, from Bahirdar)

"...I think too much tax spending has been spent on the bureaucracy, government bureaucracy has got too big and more inefficient. In terms of the main element that they spent, which is social welfare, health and education, I don 'it have problem with that...My main concerns would be corruption and that too much of the tax has been spent on building up government departments even some of them are duplication or useless and bureaucracy is too big." (Participant 1, male, from Dessie)

"I"em not really happy with [the] performance of our government. You know, the government develops and provides electrical utilities, you know, we, people es taxes bought the railways, built the dams, built the roads as well as the dams and others. „“(Participant 6, Female, from Dessie)

"...we are not clear on the details but surely all tax revenues are for the country..."

(Participant 9, male, from Gonder)

Regarding the disclosure and transparency issue of government expenditures some participants were concerned so much where they claimed that the taxpayers were not well-informed on the details of how the tax revenue was spent. They expected a full disclosure of the government expenditure allowing them to examine the accounts and demonstrating greater government accountability. For example:

"...I think there"s a lot of hidden cost[s], which has not been made public or told to the public. I think people should be informed. I think everyone has the right to be informed...There should be an open book."

(Participant 3, female, from Dessie)

"The public should be well-informed and there should always be accountability for how their tax has been used as well." (Participant 8, male, from Gonder)

"...the problem is all our money just disappears in the black hole with people who become very careless on how they use 


\section{International Journal of Science and Research (IJSR) \\ ISSN (Online): 2319-7064 \\ Index Copernicus Value (2013): 6.14 | Impact Factor (2015): 6.391}

it. While in small business if you are not careful with every single cent, you start losing everything. I want to see that same level of accountability." (Participant 21, male, Bahirdar)

With regard to the social welfare/government benefits system, despite the absence of an organized and system based welfare/benefit system and most of the time such assistance were funded by the foreign aid if any government involvement participants were generally pleased with the idea of assisting low income taxpayers to have sufficient money to live on. However, participants stated that the system must be implemented with care to ensure that wealth is distributed fairly and only to those genuinely in need. This is essential to avoid the misuse of money by those not deserving assistance. The following comments indicate participants $^{\text {ee }}$ feelings on this issue:

"Low-income people on benefits - there are times that people actually do need those benefits - and there are some people who abuse it..." (Participant 3, male, Dessie)

"Providing benefits is good for those who really deserve it but not to those who are simply lazy to find work." (nontranslated) (Participant 11, male, Gonder)

In relation to corruption the office of the tax authority at various levels are widely suspected by the public thus this sector is known for its lack of integrity and ethics. The claim of the participants in this regard is not different from the general public opinion. Some participants use waste of money and corruption interchangeably. However, the following comments illustrate the participants ${ }^{\text {ee }}$ perceptions on this issue:

„... our tax money is being used by various government authorities from Kebele (local) to high level government officials. We are paying for them not for the country...e (Participant 8, from Gonder)

". . . the tax money, the aid money and the loan from foreign creditors were not used for the intended/ appropriate purpose instead wasted, embezzled and used for nondevelopmental activities such as propaganda, series of extended useless meetings, ... „ "(Participant 1 male, from Dessie)

\subsubsection{Vertical Fairness}

Vertical fairness suggests that people in different economic situations should be taxed differently (Kirchler et al., 2006) ${ }^{[40]}$. Ideally, vertical fairness is maintained when people with higher incomes are taxed at higher rates than those with lower incomes. This idea of ability to pay is part of Distributive Justice Theory (DJT) developed by Leventhal (1976) ${ }^{[31]}$, which asserts that the ratio of inputs and outputs need not necessarily be equivalent to achieve fairness, but rather it depends on individuals ${ }^{\text {ee }}$ needs. This issue has been long considered by the Ethiopian income tax system where the progressive tax rates currently are as follows (Ethiopian Income Tax Proclamation number, 286/2002 and Income Tax Regulation number 78/2002):

(1) Zero percent on income up toETB1800;

(2) 10 percent on income ofETB1, 801 toETB7, 800;

(3) 15 percent on income of ETB7, 801 to ETB16, 800;
(4) 20 percent on income of ETB16, 801 to ETB28200;

(5) 25 percent on income of ETB 28,201 to ETB42600;

(6) 30 percent on income of ETB 42,601 to ETB60, 000;

(7) 35 percent on income ETB60, 001 and above.

This idea of progressive tax rates was, theoretically at least, agreed by the participants when they claimed that it is fair to impose higher tax rates on high-income earners rather than low-income earners. However, the implementation of the progressive tax rates under the current income tax system appeared to be unsuccessful. The results of the interviews indicate participants ${ }^{\text {ee }}$ beliefs that vertical fairness was not maintained in the tax system. The majority of participants viewed the current progressive tax rates imposed on taxpayers as unfair. Some argued that higher incomes were not sufficiently taxed - others condemned the income tax system as „oppressingee the poor and hence, there was a suggestion to not tax low-income taxpayers. The following quotes reflect these views:

"Well, I think to some people, it [the tax rate structure] seems excessive but I don't think it is sufficient for people who make a lot of money. I don't think they get taxed enough. Not based on the law but based on the practice or implementation" (Participant 2, male, from Dessie)

"I think that low income people are taxed too much. The higher income could be taxed more in practice without any change on the tax rates.” (Participant 5, male, from Dessie)

"I think people on low income shouldn"t pay any tax at all. It should be what I call a living wage that if people get below ETB24, 000 annually or whatever, they shouldn't be paying tax. " (Participant 12,female, from Gonder)

The majorities were unhappy and doubtful about the presence of vertical fairness in the current income tax system. Thus, the suggestion made by one participant to improve vertical fairness:

"The tax system should reduce the income tax rate for the low and middle income taxpayers since the gap between the rich and the poor is increasing day by day the middle income groups are changing into low income because of the economic situation in our country such as the rise of living standard due to inflation bad economic policy etc. . eee (Participant 11, from Gonder)

The results provide evidence that participants place great emphasis on vertical fairness in forming their fairness perceptions. Even though they were satisfied that progressive tax rates were in place, they had great concerns on the equality of the tax rates imposed for various income brackets and on the actual implementation of the income tax system.

\subsubsection{Retributive Fairness}

Retributive fairness suggests that, in order to be fair, the penalty imposed should match the crime or offence committed. As such, in taxation, various punishments, ranging from fines to imprisonment, are available to serve as penalties for different degrees of non-compliant behaviour. Such an understanding was shared by most of the participants in the study, who claimed the necessity of 


\section{International Journal of Science and Research (IJSR) \\ ISSN (Online): 2319-7064 \\ Index Copernicus Value (2013): 6.14 | Impact Factor (2015): 6.391}

penalty mechanisms to reinforce tax compliance among taxpayers; for example:

"...in terms of penalties, it is reasonable [to penalize] if [taxpayers] don 't want to pay. We need one mechanism to increase their awareness of their responsibility to pay." (Participant 18, male, from Bahirdar)

Likewise, participants ${ }^{\text {ee }}$ understanding of the concept of retributive fairness was implicitly expressed during the interviews where they demanded an equitable match of penalties to tax offences. The participants were of the opinion that strict penalties should be imposed on taxpayers who were deliberately avoiding or evading tax. On the other hand, more flexibility was expected from the tax authority when dealing with unintentional non-compliant taxpayers. This is because participants believed that penalizing taxpayers for their genuine mistakes is completely unfair. Unfortunately, such practices were still taking place, resulting in grievances among taxpayers towards the income tax system. The following comments are reflective of participants $^{\text {ee }}$ views in these issues:

"I think that people who do tax evasion should be hit heavily. That's different from people who missed the payment, not to run [away from paying tax] but forgetting it [unintentionally]. I think people who evaded tax deliberately should be hit with the hardest penalty." (Participant 4, female, from Dessie)

"If they are deliberately avoiding the tax, they should be penalized; if it"s a mistake, they shouldn't be penalized." (Participant 24, male, Bahirdar)

"The penalties, I"m not happy about [them] because some people cannot pay in [a] hurry and yet they get penalized." (Participant 11, male, from Gonder)

"I think there"s some unfairness around penalties for people who might make [a] mistake in calculating their tax and subsequently [are] discovered by the Revenue authorities that they hadn ${ }^{\text {eet }}$ paid enough... A few years ago, I know a number of people who through innocent mistakes were pretty well made bankrupt because they could not pay the penalties. I think the penalty rate for tax which is either late or has not been paid because of a mistake, in my understanding, is too burden [some].” (Participant 1, male, from Dessie)

Apart from the degree of penalties, some taxpayers viewed retributive fairness in terms of the relationship between the tax authority and taxpayers in relation to the mistakes made. From the participants ${ }^{\text {ee }}$ perspective, to maintain retributive fairness in the income tax system, equivalent penalties should be imposed on both the tax authority and the taxpayers for their mistakes, without any bias shown. A common example of an unfair treatment suggested by participants was the penalty interest rate, which was favorably biased towards the tax authority:

"I think it [the penalty] affects them mildly. They [the Revenue Authorities] can make mistakes and they get away with it. If we miss a day or two, they come to me like straight away, they are quite ruthless. I think the penalties are cruel." (Participant 4,female, from Dessie)

“...the penalty, there are not enough communications. One of those things is that if I am owed money, no effort is made to get the money to me. If I owed money, you know, penalty, penalty, penalty, but I" $\mathrm{m}$ not getting interest for the money they"re withholding... if I"em owed money, the money should be put in my accounts and I should be notified in my last known address, you know, rather than the money just sitting until I made the enquiry... when I have to pay it [tax] and if I owe it, they penalized straight away, while if $\mathrm{I}^{\mathrm{ec}} \mathrm{m}$ owed it, I should be given that money immediately." (Participant 7, male, from Dessie)

"The tax authority doesn't accept your accounting report based on documents they simply apply standard assessment which seems to me as one mechanism of penalty or even if they accept your provisional tax return (what you believed is true) they will let you go for the time being and they will call you after a year or so to pay additional tax with a large amount of interest according to then on the unpaid interest. This time I have no choice except to pay it or stop my business activities and return back my trading license. . .," (Participant 9 male, from Gonder)

At this point, the results indicate participants ${ }^{\text {ee }}$ belief that to maintain retributive fairness in the income tax system, the tax authority should focus on:(1) Comparability between offences and penalties; (2) Flexibility in terms of penalizing genuine mistakes; and (3) Equivalent treatment between taxpayers and the tax authority. Fulfilling these three aspects of retributive fairness is expected to improve taxpayers ${ }^{\text {ce }}$ perceptions on the retributive fairness of the income tax system.

\subsubsection{Personal Fairness}

Personal fairness basically deals with taxpayers ${ }^{\text {ee }}$ perceptions as to whether the current income tax system is fulfilling their self-interest. From the interviews conducted, it appears that participants from all income levels tended to focus on tax rates. They were unhappy with the current tax rates and wished to have lower rates. In addition, there were also comments suggesting the Ethiopian tax system should place a greater emphasis on expenditure tax and less emphasis on income tax. A selection of participants ${ }^{\text {ee }}$ comments is outlined below:

"I think people with more family should have a lower [tax] rate...anybody on low or middle income with more dependents should be taxed less." (Participant 6, female, from Dessie)

"Well, I think the top income earners are [taxed] far too much at least on paper, and I would like to see the tax rate lowered a little bit.” (Participant 14, male, from Gonder)

"It is no the actual tax that affected us more it is the estimated (standard assessment) which was not based on facts or ones true income. I personally felt that I am paying more than what is expected of me (my fair share compared to even the benefit I received from the government) because of this my life is going down. ..," 


\section{International Journal of Science and Research (IJSR) \\ ISSN (Online): 2319-7064 \\ Index Copernicus Value (2013): 6.14 | Impact Factor (2015): 6.391}

(Participant 3 male, from Dessie)

"I"m inclined to think that my personal view is that, I would put more on expenditure tax and less on the income tax. I think that because it is easier to collect and [is] generally spread across [people]."

(Participant 13, male, from Gonder)

\subsubsection{Administrative Fairness}

Administrative fairness is concerned with taxpayers ${ }^{\text {ee }}$ perceptions of how the tax authority administers the income tax system. This concept of fairness emerged from Procedural Justice Theory (PJT), which asserts that fairness in procedures may lead to fair outcomes. PJT postulates six principles underlying fair procedures, namely: consistency, bias-suppression, accuracy, correctability, representativeness, and ethicality. In relation to this study, administrative fairness of the income tax system was not only observed in terms of the above-mentioned principles, but also with a few other elements. For instance, accessibility to the tax authority has been an issue amongst the participants. In fact, there was a claim that discrimination has taken place in terms of the accessibility to the tax authority, where tax accountants and high-income taxpayers are given "privileges ee over ordinary taxpayers. This statement signals that the bias-suppression principle was violated. For instance:

"...it"s very difficult to get through to the taxation authorities. I have a query, it "s a long time just getting on to them, and then to [have them] actually speak with you." (Participant 4, female, from Dessie)

"...I do know that it is very difficult if you need to make contact each time. It is very difficult to get in touch with any of them, if you ring you can "et actually get the person and or you have to hang on for a long time. I think accountants in that sense, have special lines so that they get through to somebody, but the general public I think they get pretty frustrated." (Non-translated) (Participant 23, male, from Bahirdar)

Despite the criticisms on the accessibility of the revenue authority, some participants were quite satisfied with the tax authorityes services. However, this situation seems to be most unsatisfactory as the responsibilities to organize tax matters rests solely with the taxpayers. Participants made the following comments:

"I think the revenue authority was not well staffed both in terms of the number of employees and their necessary skills or knowledge. To have a limited amount of service they gave you long appointment. Your tax return to get audited it might take years or several months that mean until your documents are get audited you are not free from potential penalty or interest and like that. Unlike other countries the audit practice was not based on sample but all tax returns are subjected to audit so that it will take long time to be competed given the capacity of the offices and so on . . .eee (Participant 13 male from Gonder)

"I think the administration is quite good because we don't have to maintain books and accounts to prepare tax returns and most people don't have to put tax returns in because we are paying our taxes based on standard assessment every year. . ." (Participant 14, male, from Gonder)

"I think it is the fact that there is so much paperwork with the tax system and tax administration, when you get through to them, is quite efficient, we have found. But the emphasis is on the taxpayer to find the person you need, not in the other way around." (Participant 6, female, from Dessie)

Participants in this study also considered the administrative fairness of the income tax system in terms of the moral and ethical standards, which includes the friendliness of Revenue Authority staff. The participants claimed that this issue of unfriendliness was apparent particularly during a tax audit where Revenue Authority“s staff had the authority to inspect

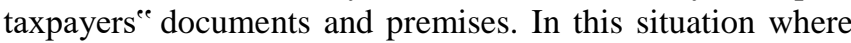
they have so much power, participants stated that Revenue Authority staff failed to convey their "good values "e through proper communication. Some of the comments offered include:

"I suspect that the tax department seems to have powers that other departments don 't have. Well, they can hound people." (Participant 17, male, from Bahirdar)

"Counter service is not good enough, not excellent but moderate. In terms of friendliness, they are not friendly; when we asked [questions], they don't answer in a friendly manner. Whatever facts they have are considered accurate, whatever facts that we bring to them, they don't want to accept."

(Participant 15, female, from Gonder)

"It [the administration system] is not user-friendly, and sometimes we sent [the tax return forms] two or three times but they claimed they did not receive it." (Non - translated) (Participant 18, male, from Bahirdar)

In order to be perceived as fair, the policy or rules employed by the revenue authority must have gone through a decisionmaking process which not only involved the tax authority, and tax experts, but also taxpayers. This PJT principle of representativeness suggests that society will be more likely to perceive a system to be fair when they have been involved in the relevant decision-making. However, the comments forwarded by one participant in this study indicates that their opinion was not sought prior to the implementation of new tax rules or policy, hence resulting in negative perceptions of the administration of the income tax system:

"The tax system/policy was not developed with the participation of the public. Just come from top to bottom and we the taxpayer felt it as burden especially when they apply the presumption tax system it was not based on facts and not consistent across time and taxpayers. It is subjected to bias and some other undesirable things ... .eee(Participant 2 male, from Dessie)

The above discussion indicates that from the participants ${ }^{\text {ee }}$ perspective, they had concerns about the administration of the income tax system in terms of (1) accessibility to the tax authority; (2) responsibility in administering tax matters; (3) 


\section{International Journal of Science and Research (IJSR) \\ ISSN (Online): 2319-7064 \\ Index Copernicus Value (2013): 6.14 | Impact Factor (2015): 6.391}

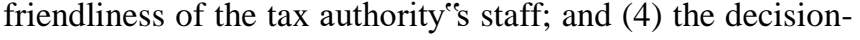
making process. Thus, all of which subsequently affected their fairness perceptions.

\subsubsection{Horizontal Fairness}

The principle of horizontal fairness is a basic yardstick used to gauge whether tax burdens are fairly distributed. On the one hand, the idea that tax policy should strive for horizontal equity is uncontroversial (Musgrave $1990^{[41]}$ ). It protects taxpayers against arbitrary discrimination, and also seems consistent with basic principles of equal worth.

Horizontal fairness is a measure of whether taxpayers in similar circumstances pay similar amounts of tax. For example, if one family pays higher taxes than a similarincome family next door, that violates "horizontal" fairness. This sort of unjustified disparity undermines public support for the tax system and diminishes people s willingness to file honest tax returns. The views of the participants in this regard were illustrated with their comments as follows:

"I think paying tax is good for development. The country doesn "et have I think enough nontax sources of revenue. Aid and loan will not support our country for long hence we have to pay tax but based on our income and indiscriminately. The main problem in this regard is when one is voluntarily or forcefully paid the right amount the other person may not do the same by himself or was not forced to pay the right amount of tax liability for various reasons. So, the tax system was not free from discrimination. ${ }^{\text {ece }}$ (Participant 17 male, from Bahirdar)

"... theoretically those who has the same income should pay the same tax but practically not true in our case as long as I know. ${ }^{\text {cee }}$ (Participant 12 female, from Gonder)

"Those who are associated with the ruling party were not paying their real tax liability. They got protection from the top authorities of the nation. We the ordinary people (helpless people) even required to pay more than our true tax liability ... e (Participant 11 male, from Gonder)

Despite the above objections on the presence of horizontal fairness in the income tax system there are some participants who argue against such criticism of course under certain conditions. The following comments of some participants indicate their perception on the horizontal fairness:

"if two tax payers having the same amount of income and anyone of them don't have the political connection with the ruling party, yes they will pay the same amount of tax. That is the practice in the tax system. ${ }^{\text {cee }}$

(Participant 4 female, from Dessie)

"it is the corruption that made identical taxpayers different . . .eee(Participant 16 female, from Bahirdar)

To sum up things about the participant's perception on the presence or absence of horizontal fairness in the income tax system the role of political interference and corruption plays a significant part and justifies the existence of inconsistent and unjust treatment among taxpayers or lack of horizontal fairness.

\subsubsection{Summary}

In this chapter, a thematic analysis of the interviews with a sample of the metropolitan cities of the Amhara Regional State of Ethiopia individual business income taxpayers was performed. The analysis involves identifying important features of the data (coding), collating the features into potential themes and reviewing the potential themes. Thereafter, the themes were defined, named and analyzed. From the analysis, the results suggest that participants had mixed perceptions on the fairness of the income tax system. Specifically they had concerns on six aspects of fairness perceptions, namely: general fairness, horizontal fairness vertical fairness, retributive fairness, personal fairness and administrative fairness. These concerns should at least provide a signal to the Revenue Authority on the aspects of income tax system that need improvements.

With regard to their impact on taxpayers ${ }^{\text {ee }}$ compliance behavior, participants generally believed that negative fairness perceptions of the income tax system have partly contributed to taxpayers ${ }^{\text {ee }}$ noncompliance

\section{Conclusion and Recommendations}

Based on the findings above in this study it is possible to conclude that business income taxpayers have multidimensional perceptions on the fairness of the income tax system. Moreover, the impact of fairness perception on the decisions of taxpayers whether to comply or not to comply with the income tax system was found to be paramount.

In the light of the above findings and conclusions the following suggestions are worth noting:

1) The revenue Authority should consider the sociopsychological aspects of the taxpayer $s^{\text {ee }}$ in addition to the economic deterrence approaches while developing the tax policy in order to make the policy implementation easy.

2) To enhance the level of tax compliance the tax authority should take the perceived tax fairness issues with all its dimensions into account.

\subsection{Limitations and Future research Directions}

This study is a qualitative approach and the next research on the topic need to be undertaken with a mixed approach to avoid the limitations of a single method approach. As indicated earlier, this study is limited to business (sole proprietorship and partnership form of business) taxpayers. Extending this study to other groups of taxpayers and to tax professionals would also be interesting. While other groups of taxpayers may generally share similar views with business taxpayers, tax professionals ${ }^{\text {ee }}$ perceptions are unknown. In addition, the focus on actual non-compliant taxpayers, if possible, would provide a further picture of the role of fairness perceptions in taxpayers ${ }^{\text {ee }}$ non-compliance behavior. Such an extension to this study could be undertaken with the assistance of the tax authority.

\subsection{Contributions of the study}

This study contributes to the body of knowledge in the field of taxation in general and to the scarcely available literature 


\section{International Journal of Science and Research (IJSR) \\ ISSN (Online): 2319-7064 \\ Index Copernicus Value (2013): 6.14 | Impact Factor (2015): 6.391}

of income taxation in Ethiopia. It could be used as additional reference for the upcoming researchers in the sub-Saharan countries and in the home country. Students of taxation can also be benefited out of this study.

\section{References}

[1] Lind, E. A., \& Tyler, T. R. (1988). The Social Psychology of Procedural Justice. New York: Plenum Press.

[2] Rasinski, K., \& Tyler, T. R. (1988). Fairness and voter choice in the 1984 presidential election. American Politics Quarterly, 4-24.

[3] Etzioni, A. (1986). Tax evasion and perceptions of tax fairness: A research note. The Journal of Applied Behavioural Science, 22(2), 177-185.

[4] Bordignon, M. (1993). A fairness approach to income tax evasion. Journal of Public Economics, 52(3), 345362.

[5] Alm ,J. , and Mckee, M. (2006). Audit Certainty, Audit Productivity, and Taxpayer Compliance. National Tax Journal.

[6] Slemrod, J. (1992). Taxation and Inequality; A Time Exposure Perspective. The National Bureau of Economic Research (NBER), working paper no.3999, Cambridge, MA 02138.

[7] Alm,J. (1999), Tax compliance and administration, in H. Bartley \& J.A. Richardson (eds), Handbook on Taxation, New York: Marcel Dekker, pp. 741 - 68.

[8] Taddese Lencho. (2014) . The Ethiopian income tax system: policy, design and practice. Dissertation, University of Alabama, unpublished pp. $272-84$.

[9] Wubshet ,A. (2011). Taxpayerse perceptions towards fairness: personal business profit taxpayers in Addis Ababa, unpublished thesis, Addis Ababa University, pp. $76-100$.

[10] Asmamaw, Y. (2014). Comparative study of compliant and non-compliant individual taxpayers in Ethiopia from Amhara Region. Iournal of Economics and Sustainable Development. Vol.5, no.24, pp 10 -16.

[11] Tsegabirhan, W. (2010). Domestic Resource Mobilization in Sub - Saharan Africa: The case of Ethiopia. AAU, unpublished , PP. 10- 16.

[12] IMF. (2015).The Democratic Republic of Ethiopia. Press Release. Country Report No.15/300

[13] Adams, J. S. (1965). Inequity in social exchange. In L. Berkowitz (Ed.), Advances in Experimental Psychology (pp. 267-299). New York: Academic Press.

[14] Greenberg, J. (1987). A taxonomy of organizational justice theories. The Academy of Management Review, 12(1), 9-22.

[15] Eckhoff, T. (1974). Justice: Its Determinants in Social Interaction. Rotterdam: Rotterdam Press.

[16] Leventhal, G. S. (1980). What should be done with equity theory? In K. J. Gergen, M. S. Greenberg \& R. H. Willis (Eds.), Social Exchange: Advances in Theory and Research (pp. 27-55). New York: Plenum.

[17] Thibaut, J. W., \& Walker, L. (1975). Procedural Justice: A Psychological Analysis. Hillsdale: Lawrence Erlbaum.

[18] Aryee, S., Chen, Z. X., \& Budhwar, P. S. (2004). Exchange fairness and employee performance: An examination of the relationship between organizational politics and procedural justice. Organizational Behaviour and Human Decision Processes, 94(1), 1-14.

[19] Campbell, J. P., \& Pritchard, R. A. (1976). Motication theory in industrial and organizational psychology. In M. D. Dunnette (Ed.), Handbook of Industrial and Organizational Psychology (pp. 63-130). Chicago: Rand McNally.

[20] Watson, R., Storey, D., Wynarczyk, P., Keasey, K., \& Short, H. (1996). The relationship between job satisfaction and managerial remuneration in small and medium-sized enterprises: An empirical test of 'comparison income' and 'equity theory' hypotheses. Applied Economics, 28(5), 567-576.

[21] Bobek, D. D. (1997). Tax fairness: How do individuals judge fairness and what effect does it have on their behavior? Unpublished manuscript, University of Florida, Michigan.

[22] Carnes, G. A., \& Cuccia, A. D. (1996). An analysis of the effect of tax complexity and its perceived justification on equity judgments. Journal of the American Taxation Association, 18, 40-56.

[23] Gilligan, G., \& Richardson, G. (2005). Perceptions of tax fairness and tax compliance in Australia and Hong Kong: A preliminary study. Journal of Financial Crime, 14(4), 331-343.

[24] Douglas, D. E., Cronan, T. P., \& Behel, J. D. (2007). Equity perceptions as a deterrent to software piracy behaviour. Information \& Management, 44(5), 503-512.

[25] Joshi, K. (1989). The measurement of fairness or equity perceptions of management information system users. MIS Quarterly, 13(3), 343-358.

[26] Cook, K. S., \& Hegtvedt, K. A. (1983). Distributive justice, equity and equality. Annual Review of Sociology, 9, 217-241.

[27] Blalock, H. M., \& Wilken, R. H. (1979). Intergroup Processes: A Micromacro Perspective. New York: Free Press.

[28] Lamm, H., \& Schwinger, T. (1980). Norms concerning distributive justice: Are needs taken into consideration in allocation decisions? Social Psychology Quarterly, 43(4), 425-429.

[29] Walster, E., Walster, G. W., \& Berscheid, E. (1978). Equity: Theory and Research. Boston: Allyn and Balcon.

[30] Schwinger, T. (1980). Just allocation of goods: Decisions among three principles. In G. Mikula (Ed.), Justice and Social Interaction (pp. 95-125). New York: Springer-Verlag.

[31] Leventhal, G. S. (1976). The distribution of rewards and resources in groups and organizations. In L. Berkowitz \& E. Walster (Eds.), Advances in Experimental Social Psychology (pp. 91-131). New York: Academic Press.

[32] Fuller, L. (1961). The adversary system. In H. Berman (Ed.), Talks on American Law (pp. 10-22). New York: Vintage Books.

[33] Leventhal, G. S., Karuza, J., \& Fry, W. R. (1980). Beyond fairness: A theory of allocation preferences. In G. Mikula (Ed.), Justice and Social Interaction (pp. 167-218). New York: Springer-Verlag. Synodinos, N. (2003). The 'art' of questionnaire construction: Some important considerations for manufacturing studies. Integrated Manufacturing Systems, 14(3), 221-237. 
[34] Barret, H. E., \& Tyler, T. R. (1986). Procedural justice as a criterion in allocation decisions. Journal of Personality and Social Psychology, 50(2), 296-304.

[35] Fry, W. R., \& Cheney, G. (1981). Perceptions of procedural fairness as a function of distributive preference. Paper presented at the Meeting of the Midwestern Psychological Association.

[36] Makkai, T., \& Braithwaite, J. (1996). Procedural justice and regulatory compliance. Law and Human Behaviour, 20(1), 83-98.

[37]Hair, J. J. F., Money, A. H., Samouel, P., \& Page, M. (2007). Research methods for business. London: John Wiley \& Sons Ltd.

[38] Synodinos, N. (2003). The 'art' of questionnaire construction: Some important considerations for manufacturing studies. Integrated Manufacturing Systems, 14(3), 221-237.

[39] Braun, V., \& Clarke, V. (2006). Using thematic analysis in psychology. Qualitative Research in Psychology, 3, 77-101.

[40] Kirchler, E., Niemirowski, A., \& Wearing, A. (2006). Shared subjective views, intent to cooperate and tax compliance: Similarities between Australian taxpayers and tax officers. Journal of Economic Psychology, 27(4), 502-517.

[41] Musgrave, Richard A. "Horizontal Equity: Once More." National Tax Journal. vol. 43, No. 2, (June 1990)

\section{Appendix 1}

List of interview questions

1) What do you think of the current income tax system?

2) Is it fair/ unfair? Could you please elaborate on the aspects that you think it is fair/unfair?

3) What do you think are the major determinants of tax fairness perceptions?

4) If you 'ere given a chance to improve the current tax system, which aspect would you focus on?

5) About compliance behaviour, do you believe that generally taxpayers from every level of income comply?

6) Do you think that compliance behaviour is affected by people's perceptions on the fairness of the income tax system?

7) Do you think the middle-income earners are being treated fairly under the current tax system?

8) What is your opinion about the belief that high-income earners can easily evade tax with the help from tax consultants?

9) Do you agree that the low-income earners receive a lot of benefits despite of the low tax paid?

10) Any other comments? 